Article

\title{
Two New Succinimide Derivatives Cladosporitins A and $B$ from the Mangrove-derived Fungus Cladosporium sp. HNWSW-1
}

\author{
Pei Wang ${ }^{1,2, \dagger}$, Yan Cui ${ }^{1,2, \dagger}$, Caihong Cai ${ }^{1,2}$, Huiqin Chen ${ }^{1,2}$, Yu Dai ${ }^{1,2}$, Pengwei Chen ${ }^{1,2}$, \\ Fandong Kong 1,2 , Jingzhe Yuan ${ }^{1,2}$, Xinming Song ${ }^{3}$, Wenli Mei ${ }^{1,2, *}$ and Haofu Dai ${ }^{1,2, *}$ \\ 1 Key Laboratory of Biology and Genetic Resources of Tropical Crops, Ministry of Agriculture, Institute of \\ Tropical Bioscience and Biotechnology, Chinese Academy of Tropical Agricultural Sciences, \\ Haikou 571101, China; wangpei@itbb.org.cn (P.W.); cuiyan502@163.com (Y.C.); \\ caicaihong@itbb.org.cn (C.C.); chenhuiqin@itbb.org.cn (H.C.); daiyu15@mails.ucas.ac.cn (Y.D.); \\ chenpengwei@itbb.org.cn (P.C.); kongfandong@itbb.org.cn (F.K.); yuanjingzhepc@126.com (J.Y.) \\ 2 Hainan Key Laboratory for Research and Development of Natural Product from Li Folk Medicine, \\ Haikou 571101, China \\ 3 Key Laboratory of Tropical Medicinal Plant Chemistry of Ministry of Education and Hainan Normal \\ University, Haikou 571101, China; sxm8646@163.com \\ * Correspondence: meiwenli@itbb.org.cn (W.M.); daihaofu@itbb.org.cn (H.D.); \\ Tel./Fax: +86-0898-6698-7529 (W.M.); +86-0898-6696-1869 (H.D.) \\ + These authors contributed equally to this work.
}

Received: 29 November 2018; Accepted: 17 December 2018; Published: 20 December 2018

\begin{abstract}
Two new succinimide-containing derivatives, cladosporitins A (1) and B (2), were isolated from the fermentation cultures of the mangrove-derived fungus Cladosporium sp. HNWSW-1, along with a new pyrone, clapone (3), as well as the previously reported talaroconvolutin A (4) and anthraquinone (5). The structures of the isolated compounds were elucidated by 1D, 2D NMR, and HRMS spectral analysis. Compound 2 showed cytotoxicity against BEL-7042, K562 and SGC-7901 cell lines with $\mathrm{IC}_{50}$ values of $29.4 \pm 0.35 \mu \mathrm{M}, 25.6 \pm 0.47 \mu \mathrm{M}$, and $41.7 \pm 0.71 \mu \mathrm{M}$, respectively, whereas compound 4 exhibited cytotoxicity against Hela and BEL-7042 cell lines with $\mathrm{IC}_{50}$ values of $14.9 \pm 0.21 \mu \mathrm{M}$ and $26.7 \pm 1.1 \mu \mathrm{M}$, respectively. In addition, compounds 4 and 5 displayed inhibitory activity against $\alpha$-glycosidase, with $\mathrm{IC}_{50}$ values of $78.2 \pm 2.1 \mu \mathrm{M}$ and $49.3 \pm 10.6$ $\mu \mathrm{M}$, respectively.
\end{abstract}

Keywords: mangrove-derived fungus; Cladosporium sp.; succinimide-containing derivatives; cytotoxicity; $\alpha$-glycosidase inhibitor

\section{Introduction}

Fungi are an important resource of structurally and biologically diverse substances for drug and pesticide discovery [1-7]. A set of rare natural compounds from fungi, such as talaroconvolutins A-D, ZG-1494R, oteromycin, and codinaeopsin, which contain a modified tetramic acid unit linked to phenol, benzene, or indole and decalin fragments, exhibit activities against fungi, platelet-activating factors, acetyltransferase, endothelins receptors, or Plasmodium falciparum [8-11]. During our ongoing search for new bioactive metabolites from marine fungi, Cladosporium sp. HNWSW-1 was isolated from the healthy tree root of Ceriops tagal collected from the Dong Zhai Gang Mangrove Reserve in Hainan. The secondary metabolites of the genus Cladosporium have been mainly reported as polyketides derivatives, such as fatty acids [12], macrolides [13-15], pyrones [16-18], binaphthyl derivatives [19,20], $\alpha$-pyridone [21] and tetramic acid derivatives [22,23]. Subsequent chemical investigations on the 
EtOAc extract of its fermentation cultures led to the isolation of cladosporitins A (1) and B (2), which contain the succinimide unit linked to phenol and decalin fragments. In addition, a new pyrone, clapone (3), was also isolated along with the previously reported talaroconvolutin A (4) [8] and 1,3,6-trihydroxy-7-(1-hydroxyethyl) anthracene-9,10-dione (5) [24]. Herein, we describe the isolation, structural determination, and biological activities of compounds 1-5.

\section{Results}

\subsection{Structural Elucidation}

Compound 1 was isolated as yellow oil. Its molecular formula was determined as $\mathrm{C}_{32} \mathrm{H}_{43} \mathrm{NO}_{4}$ by HRESIMS $m / z 528.3103[\mathrm{M}+\mathrm{Na}]^{+}$(calcd. for $\mathrm{C}_{32} \mathrm{H}_{43} \mathrm{NO}_{4} \mathrm{Na}$ 528.3084) (Figure $\mathrm{S} 18$ in Supplementary Materials). The ${ }^{1} \mathrm{H}$, DEPTQ and HSQC NMR spectra (Figures S1, S2, and S6-S8 in Supplementary Materials) of compound 1 showed signals of one ketone carbonyl at $\delta_{\mathrm{C}} 203.9$, two amide carbonyls at $\delta_{\mathrm{C}} 172.7$ and $\delta_{\mathrm{C}} 179.2$, a para-substituted benzene ring $\left(\delta_{\mathrm{C}} 131.5 / \delta_{\mathrm{H}} 7.10, \delta_{\mathrm{C}} 116.3 / \delta_{\mathrm{H}} 6.77, \delta_{\mathrm{C}}\right.$ 157.5 and $\left.\delta_{\mathrm{C}} 128.1\right)$, seven $s p^{3}$ methines $\left(\delta_{\mathrm{C}} 61.7, \delta_{\mathrm{C}} 52.9, \delta_{\mathrm{C}} 51.8, \delta_{\mathrm{C}} 45.0, \delta_{\mathrm{C}} 40.8, \delta_{\mathrm{C}} 34.8\right.$, and $\delta_{\mathrm{C}}$ 28.1), two $s p^{2}$ methines $\left(\delta_{C} 137.1\right.$ and $\left.\delta_{C} 136.7\right)$, five methylenes $\left(\delta_{C} 49.1, \delta_{C} 36.5, \delta_{C} 35.8, \delta_{C} 31.1\right.$, and $\left.\delta_{C} 24.1\right)$, and six methyls $\left(\delta_{C} 23.1, \delta_{C} 22.5, \delta_{C} 21.1, \delta_{C} 20.5, \delta_{C} 15.2\right.$, and $\left.\delta_{C} 12.4\right)$ (Table 1 ), except in the above data there were also three quaternary carbons $\left(\delta_{\mathrm{C}} 130.7, \delta_{\mathrm{C}} 135.7\right.$, and $\left.\delta_{\mathrm{C}} 36.2\right)$. The comparison of ${ }^{1} \mathrm{H}$ and ${ }^{13} \mathrm{C}$ NMR data (Table 1 ) of the previously reported talaroconvolutin $\mathrm{A}$ (4) [8] revealed many similarities. Compound $\mathbf{1}$ had the same decalin moiety with the substituent that is the 4-methylhex-2-en-2-yl substituent linked to $C-15\left(\delta_{C} 51.8\right)$ as compound 4 . This is evidenced by the sequential COSY correlations (Figures S3-S5 in Supplementary Materials) from H-15 $\left(\delta_{\mathrm{H}} 3.10\right)$ through $\mathrm{H}_{3}-33\left(\delta_{\mathrm{H}} 0.82\right)$, and $\mathrm{H}_{2}-18\left(\delta_{\mathrm{H}} 1.48 / 0.87\right)$, from $\mathrm{H}_{3}-28\left(\delta_{\mathrm{H}} 0.86\right)$ through $\mathrm{H}-25\left(\delta_{\mathrm{H}} 5.05\right)$ and $\mathrm{H}_{3}-29\left(\delta_{\mathrm{H}}\right.$ $0.92)$, as well as by HMBC correlations (Figures S9-S14 in Supplementary Materials) from $\mathrm{H}-14\left(\delta_{\mathrm{H}}\right.$ $3.62)$ to $\mathrm{C}-23\left(\delta_{\mathrm{C}} 36.2\right)$, and C-24 $\left(\delta_{\mathrm{C}} 135.7\right)$, from $\mathrm{H}-15$ to $\mathrm{C}-17\left(\delta_{\mathrm{C}} 137.1\right), \mathrm{C}-22\left(\delta_{\mathrm{C}} 40.8\right), \mathrm{C}-24, \mathrm{C}-30\left(\delta_{\mathrm{C}}\right.$ $15.2)$, and $\mathrm{C}-31\left(\delta_{\mathrm{C}} 22.5\right)$, from $\mathrm{H}-17\left(\delta_{\mathrm{H}} 5.38\right)$ to $\mathrm{C}-15, \mathrm{C}-18\left(\delta_{\mathrm{C}} 49.1\right), \mathrm{C}-31$, and $\mathrm{C}-32\left(\delta_{\mathrm{C}} 20.5\right)$, from $\mathrm{H}_{2}-18$ to $\mathrm{C}-20\left(\delta_{\mathrm{C}} 36.5\right), \mathrm{C}-22$, and C-33 $\left(\delta_{\mathrm{C}} 23.1\right)$, from $\mathrm{H}-22\left(\delta_{\mathrm{H}} 1.78\right)$ to C-20, C-21 $\left(\delta_{\mathrm{C}} 24.1\right)$, and C-23, from $\mathrm{H}_{3}-31\left(\delta_{\mathrm{H}} 1.54\right)$ to $\mathrm{C}-15, \mathrm{C}-16\left(\delta_{\mathrm{C}} 130.7\right)$, and C-17, from $\mathrm{H}_{3}-33$ to $\mathrm{C}-18$ and $\mathrm{C}-20$, from $\mathrm{H}_{3}-32\left(\delta_{\mathrm{H}}\right.$ $0.91)$ to $\mathrm{C}-17, \mathrm{C}-18, \mathrm{C}-22$, and C-23, from H-25 to C-15, C-26 $\left(\delta_{\mathrm{C}} 34.8\right), \mathrm{C}-27\left(\delta_{\mathrm{C}} 31.1\right), \mathrm{C}-29\left(\delta_{\mathrm{C}} 21.1\right)$, and $\mathrm{C}-30\left(\delta_{\mathrm{C}} 15.2\right)$, from $\mathrm{H}-26\left(\delta_{\mathrm{H}} 2.25\right)$ to $\mathrm{C}-27, \mathrm{C}-28\left(\delta_{\mathrm{C}} 12.4\right)$, and $\mathrm{C}-29$, as well as from $\mathrm{H}_{3}-29$ to $\mathrm{C}-25\left(\delta_{\mathrm{C}} 136.7\right), \mathrm{C}-26$, and C-27. The differences between compounds 1 and 4 are that the modified tetramic acid unit, 1,5-dihydro-2H-pyrrol-2-one unit, and C-6/C -7 double bond in compound 4 were replaced by the succinimide unit and $\mathrm{CH}_{2}-6 / \mathrm{CH}-7$ unit in compound 1, respectively, as deduced by the sequential COSY correlations (Figures S3-S5 in Supplementary Materials) from H-3 $\left(\delta_{\mathrm{H}} 4.06\right)$ to $\mathrm{H}_{2}-6$ $\left(\delta_{\mathrm{H}} 3.11 / 2.87\right)$ through $\mathrm{H}-4\left(\delta_{\mathrm{H}} 3.40\right)$ and the HMBC correlations (Figures S9-S14 in Supplementary Materials) from H-3 to C-2 $\left(\delta_{\mathrm{C}} 172.7\right) / \mathrm{C}-4\left(\delta_{\mathrm{C}} 45.0\right) / \mathrm{C}-5\left(\delta_{\mathrm{C}} 179.2\right) / \mathrm{C}-6\left(\delta_{\mathrm{C}} 35.8\right)$, from H-4 to C-2/C-3 $\left(\delta_{\mathrm{C}} 61.7\right) / \mathrm{C}-5 / \mathrm{C}-6 / \mathrm{C}-7\left(\delta_{\mathrm{C}} 128.1\right)$, and from $\mathrm{H}_{2}-6$ to C-3/C-4/C-5/C-7/C-8 $\left(\delta_{\mathrm{C}} 131.5\right)$. In addition, the COSY and $\mathrm{HMBC}$ correlations suggested that the para-disubstituted benzene ring was linked to C-4 in compound 1 via C- 6 . Finally, the key HMBC correlations from H-3 and H-4 to C-13 $\left(\delta_{\mathrm{C}} 203.9\right)$ and from $\mathrm{H}-14$ to $\mathrm{C}-13$ confirmed that the decalin and the succinimide fragments were linked through a ketone carbonyl (C-13). According to the molecular formula and the chemical shift of C-10 $\left(\delta_{\mathrm{C}}\right.$ 157.5 ) in compound 1, a hydroxyl group was present on C-10. ROESY correlations (Figures S15-S17 in Supplementary Materials) from $\mathrm{H}-14$ and $\mathrm{H}-19$ to $\mathrm{H}_{3}-32$ suggested the relative configurations of $\mathrm{C}-14$, $\mathrm{C}-19$, and C-23 as shown in Figure 1. The large coupling constant $(J=12.0 \mathrm{~Hz})$ of H-14/H-22 indicated their trans-diaxial orientation, while a coupling constant of $7.0 \mathrm{~Hz}$ between $\mathrm{H}-14$ and $\mathrm{H}-15$ placed these two protons in an axial-equatorial orientation $[9,11]$. Moreover, the ROESY correlation from $\mathrm{H}-3$ to $\mathrm{H}_{2}-6$ $\left(\delta_{\mathrm{H}} 2.87\right)$ hinted that $\mathrm{H}-3$ and $\mathrm{H}-4$ were on opposite sides of the succinimide ring. ROESY correlations (Figures S15-S17 in Supplementary Materials) from $\mathrm{H}_{3}-30$ to $\mathrm{H}-26$ and from $\mathrm{H}-25$ to $\mathrm{H}-15$ proved the E-configuration of $\Delta^{24}$ double bond. Thus, the structure of compound $\mathbf{1}$ was established as shown in Figure 1 and was named cladosporitin A. However, the relative relationship between the chiral 
carbons in the succinimide fragment and those in the decalin fragment cannot be determined due to the free rotation of the $\mathrm{C}-3 / \mathrm{C}-13 / \mathrm{C}-14$ linkage.

Table 1. ${ }^{1} \mathrm{H}$ and ${ }^{13} \mathrm{C}$ NMR Data for compound 1 (600 and $150 \mathrm{MHz}, \delta$ in ppm) and compound 2 (500 and $125 \mathrm{MHz}, \delta$ in ppm).

\begin{tabular}{|c|c|c|c|c|}
\hline \multirow{2}{*}{ Position } & \multicolumn{2}{|r|}{$1^{a}$} & \multicolumn{2}{|r|}{$2^{b}$} \\
\hline & $\delta_{\mathrm{C}}$, Type & $\delta_{\mathrm{H}}$, Mult. $(J$ in $\mathrm{Hz})$ & $\delta_{\mathrm{C}}$, Type & $\delta_{\mathrm{H}}$, mult. $(J$ in $\mathrm{Hz})$ \\
\hline 1 & - & - & - & - \\
\hline 2 & $172.7, \mathrm{C}$ & - & $172.0, \mathrm{C}$ & - \\
\hline 3 & 61.7, CH & $4.06, \mathrm{~d},(2.4)$ & $61.9, \mathrm{CH}$ & $3.40, \mathrm{~d},(4.1)$ \\
\hline 4 & $45.0, \mathrm{CH}$ & $3.40, \mathrm{~m}$ & $43.6, \mathrm{CH}$ & $3.67, \mathrm{~m}$ \\
\hline 5 & $179.2, \mathrm{C}$ & & $178.3, \mathrm{C}$ & - \\
\hline 6 & $35.8, \mathrm{CH}_{2}$ & $\begin{array}{l}3.11, \mathrm{dd},(14.7,5.9) \\
2.87, \mathrm{dd},(14.7,5.3)\end{array}$ & 35.0, $\mathrm{CH}_{2}$ & $\begin{array}{l}3.10, \mathrm{dd},(13.7,5.1) \\
2.79, \mathrm{dd},(13.7,8.7)\end{array}$ \\
\hline 7 & $128.1, \mathrm{C}$ & - & $128.2, \mathrm{C}$ & - \\
\hline 8 & $131.5, \mathrm{CH}$ & $7.10, \mathrm{~d},(8.3)$ & $130.5, \mathrm{CH}$ & $6.99, \mathrm{~d},(8.7)$ \\
\hline 9 & $116.3, \mathrm{CH}$ & $6.77, \mathrm{~d},(8.3)$ & $115.9, \mathrm{CH}$ & $6.75 \mathrm{~d},(8.7)$ \\
\hline 10 & $157.5, \mathrm{C}$ & - & $155.4, \mathrm{C}$ & - \\
\hline 11 & $116.3, \mathrm{CH}$ & $6.77, \mathrm{~d}(8.3)$ & $115.9, \mathrm{CH}$ & $6.75, \mathrm{~d},(8.7)$ \\
\hline 12 & $131.5, \mathrm{CH}$ & $7.10, \mathrm{~d}(8.3)$ & $130.5, \mathrm{CH}$ & $6.99, \mathrm{~d},(8.7)$ \\
\hline 13 & $203.9, C$ & - & $202.2, \mathrm{C}$ & - \\
\hline 14 & $52.9, \mathrm{CH}$ & $3.62, \mathrm{dd}(12.0,7.0)$ & $52.6, \mathrm{C}$ & $3.33, \mathrm{dd},(12.1,6.9)$ \\
\hline 15 & $51.8, \mathrm{CH}$ & $3.10 \mathrm{~m}$ & $50.9, \mathrm{CH}$ & $2.95, \mathrm{~d},(6.9)$ \\
\hline 16 & $130.7, \mathrm{C}$ & - & $130.1, \mathrm{C}$ & - \\
\hline 17 & 137.1, $\mathrm{CH}$ & $5.38, \mathrm{~s}$ & $135.8, \mathrm{CH}$ & $5.29, \mathrm{~s}$ \\
\hline 18 & $49.1, \mathrm{CH}_{2}$ & $\begin{array}{l}1.48, \mathrm{~m} \\
0.87, \mathrm{~m}\end{array}$ & $48.3, \mathrm{CH}_{2}$ & $\begin{array}{l}1.43, \mathrm{~m} \\
0.86, \mathrm{~m}\end{array}$ \\
\hline 19 & $28.1, \mathrm{CH}$ & $1.66, \mathrm{~m}$ & $27.4, \mathrm{CH}$ & $1.61, \mathrm{~m}$ \\
\hline 20 & $36.5, \mathrm{CH}_{2}$ & $\begin{array}{l}1.64, \mathrm{~m} \\
0.82, \mathrm{~m}\end{array}$ & $35.6, \mathrm{CH}_{2}$ & $\begin{array}{l}1.60, \mathrm{~m} \\
0.77, \mathrm{~m}\end{array}$ \\
\hline 21 & 24.1, $\mathrm{CH}_{2}$ & $\begin{array}{l}1.32, \mathrm{~m} \\
0.96, \mathrm{~m}\end{array}$ & 24.3, $\mathrm{CH}_{2}$ & $\begin{array}{l}1.62, \mathrm{~m} \\
0.75, \mathrm{~m}\end{array}$ \\
\hline 22 & $40.8, \mathrm{CH}$ & $\begin{array}{c}\text { 1.78, ddd, }(12.0 \\
12.0,2.3)\end{array}$ & $42.2, \mathrm{CH}$ & $1.67, \mathrm{~m}$ \\
\hline 23 & $36.2, \mathrm{C}$ & - & $35.2, \mathrm{C}$ & - \\
\hline 24 & $135.7, \mathrm{C}$ & - & $135.0, \mathrm{C}$ & - \\
\hline 25 & 136.7, $\mathrm{CH}$ & $5.05, \mathrm{~d},(8.2)$ & 136.1, $\mathrm{CH}$ & $4.66, \mathrm{~d},(9.3)$ \\
\hline 26 & $34.8, \mathrm{CH}$ & $2.25, \mathrm{~m}$ & $33.9, \mathrm{CH}$ & $2.14, \mathrm{~m}$ \\
\hline 27 & $31.1, \mathrm{CH}_{2}$ & $\begin{array}{l}1.35, \mathrm{~m} \\
1.23, \mathrm{~m}\end{array}$ & $30.4, \mathrm{CH}_{2}$ & $\begin{array}{l}1.27, \mathrm{~m} \\
1.10, \mathrm{~m}\end{array}$ \\
\hline 28 & $12.4, \mathrm{CH}_{3}$ & $0.86, \mathrm{t},(7.6)$ & $12.1, \mathrm{CH}_{3}$ & $0.79, \mathrm{t},(7.1)$ \\
\hline 29 & $21.1, \mathrm{CH}_{3}$ & $0.92, \mathrm{~d},(6.2)$ & $20.9, \mathrm{CH}_{3}$ & $0.76, d,(6.6)$ \\
\hline 30 & $15.2, \mathrm{CH}_{3}$ & $1.45, \mathrm{~s}$ & $14.5, \mathrm{CH}_{3}$ & $1.47, \mathrm{~s}$ \\
\hline 31 & $22.5, \mathrm{CH}_{3}$ & $1.54, \mathrm{~s}$ & $22.2, \mathrm{CH}_{3}$ & $1.46, \mathrm{~s}$ \\
\hline 32 & $20.5, \mathrm{CH}_{3}$ & $0.91, \mathrm{~s}$ & $20.3, \mathrm{CH}_{3}$ & $0.85, \mathrm{~s}$ \\
\hline 33 & $23.1, \mathrm{CH}_{3}$ & $0.82, \mathrm{~d},(6.4)$ & $22.8, \mathrm{CH}_{3}$ & $0.82, \mathrm{~d},(6.2)$ \\
\hline
\end{tabular}

${ }^{\mathrm{a}}$ Recorded in Acetone; ${ }^{\mathrm{b}}$ Recorded in $\mathrm{CDCl}_{3}$. 

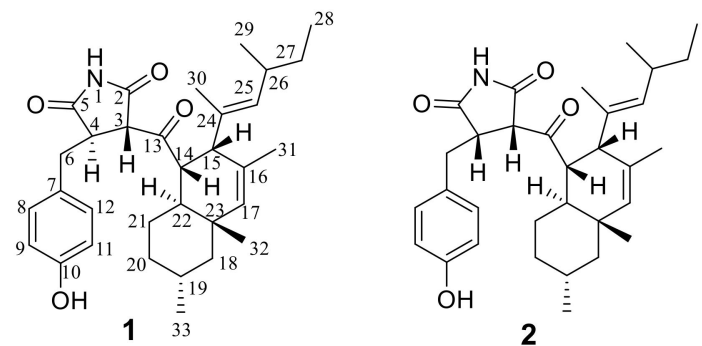<smiles>CC=Cc1cc(=O)c2c(C)cc(O)cc2o1</smiles>

3

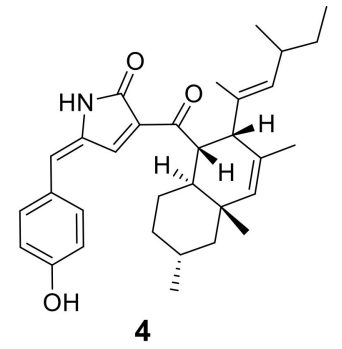<smiles>C[C@H](O)c1cc2c(cc1O)C(=O)c1cc(O)cc(O)c1C2=O</smiles>

Figure 1. Chemical structures of compounds 1-5 from Cladosporium sp. HNWSW-1.

Compound 2 was also isolated as a yellow oil with the same molecular formula as compound 1, as determined by the HRESIMS peak at $m / z 506.3279[\mathrm{M}+\mathrm{H}]^{+}$(calcd. for $\mathrm{C}_{32} \mathrm{H}_{44} \mathrm{NO}_{4} 506.3265$ ) (Figure S39 in Supplementary Materials). A detailed comparison of NMR data of compound 2 (Figures S19-S36 in the Supplementary Materials and Table 1) with those of compound $\mathbf{1}$ indicated that compound $\mathbf{2}$ had the same planar structure as compound 1. ROESY correlations (Figures S37 and S38 in Supplementary Materials and Figure 2) from $\mathrm{H}-14$ and $\mathrm{H}-19$ to $\mathrm{H}_{3}-32$ along with the coupling constant of $\mathrm{H}-14 / \mathrm{H}-22(\mathrm{~J}=12.1 \mathrm{~Hz})$ and $\mathrm{H}-14 / \mathrm{H}-15(\mathrm{~J}=6.9 \mathrm{~Hz})$ suggested that the relative configurations of C-14, C-15, C-19, C-22, and C-23 in the decalin fragment of compound 2 were the same as those of compound 1. However, the relatively large coupling constant between $\mathrm{H}-3$ and $\mathrm{H}-4$ of compound 2 $(J=4.1 \mathrm{~Hz})$ compared to compound $\mathbf{1}(J=2.4 \mathrm{~Hz})$ combined with the absence of the ROESY correlation of $\mathrm{H}-3 / \mathrm{H}_{2}-6\left(\delta_{\mathrm{H}} 3.10 / 2.79\right)$ in compound 2 suggested the cis orientation of $\mathrm{H}-3$ and $\mathrm{H}-4$, which is different than that of compound $\mathbf{1}$. Thus, compound $\mathbf{2}$ was elucidated as shown in Figure 1 and named cladosporitin B.

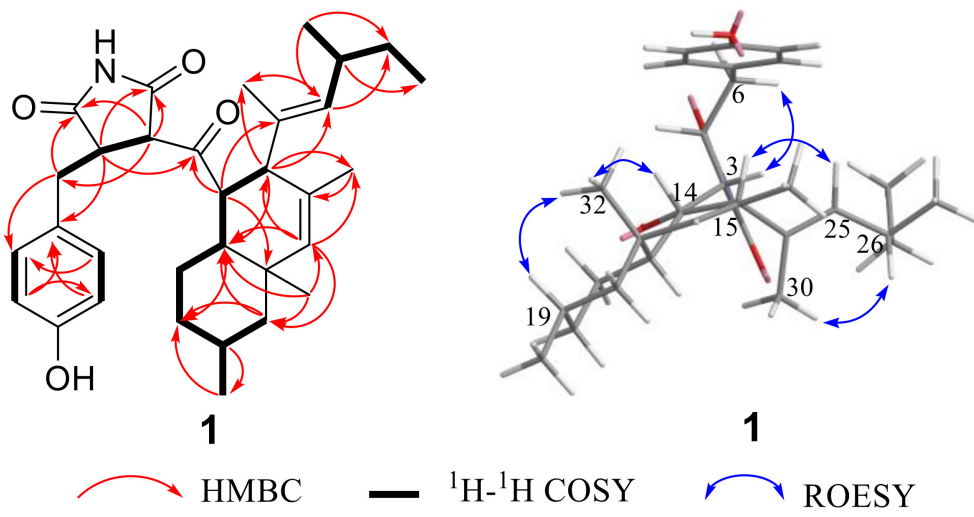

Figure 2. The key 2D NMR correlations for compound 1.

Compound 3, a yellow oil, exhibited a prominent sodium adduct ion peak at $\mathrm{m} / z 239.0676$ [M $+\mathrm{Na}]^{+}$in the HRESIMS spectrum (Figure S50 in Supplementary Materials), suggesting a molecular formula of $\mathrm{C}_{13} \mathrm{H}_{12} \mathrm{O}_{3}$. Analysis of ${ }^{1} \mathrm{H} \mathrm{NMR},{ }^{13} \mathrm{C}$ NMR, and HSQC spectra (Figures S40-S42 and S44-46 in Supplementary Materials) displayed five aromatic or olefinic methines $\left(\delta_{\mathrm{C}} 137.3 / \delta_{\mathrm{H}} 6.86\right.$, $\delta_{\mathrm{C}} 124.8 / \delta_{\mathrm{H}} 6.26, \delta_{\mathrm{C}} 118.3 / \delta_{\mathrm{H}} 6.64, \delta_{\mathrm{C}} 109.9 / \delta_{\mathrm{H}} 6.01$, and $\left.\delta_{\mathrm{C}} 101.8 / \delta_{\mathrm{H}} 6.70\right)$, two methyl siglets $\left(\delta_{\mathrm{C}}\right.$ $23.1 / \delta_{\mathrm{H}} 2.73$ and $\left.\delta_{\mathrm{C}} 18.6 / \delta_{\mathrm{H}} 1.99\right)$, three sp ${ }^{2}$ oxyquaternary carbons $\left(\delta_{\mathrm{C}} 164.0, \delta_{\mathrm{C}} 162.0\right.$, and $\left.\delta_{\mathrm{C}} 161.0\right)$, 
two sp ${ }^{2}$ quaternary carbons $\left(\delta_{\mathrm{C}} 143.6\right.$ and $\left.\delta_{\mathrm{C}} 115.8\right)$, and one carbonyl $\left(\delta_{\mathrm{C}} 182.3\right)$ (Table 2$)$. The ${ }^{1} \mathrm{H}$ NMR and ${ }^{13} \mathrm{C}$ NMR data of compound 3 (Table 2) were very similar to those of 7-hydroxy-5-methyl-2(2-oxobutyl)-4H-chromen-4-one [25]. The only major difference between them was the substituent linked to the 7-hydroxy-5-methyl-4H-chromen-4-one nucleus on C-2. The COSY correlations (Figure $\mathrm{S} 43$ in Supplementary Materials) of $\mathrm{H}-1^{\prime}\left(\delta_{\mathrm{H}} 6.26\right) / \mathrm{H}-2^{\prime}\left(\delta_{\mathrm{H}} 6.86\right) / \mathrm{H}-3^{\prime}\left(\delta_{\mathrm{H}} 1.99\right)$, along with the HMBC correlations (Figures S47-S49 in Supplementary Materials and Figure 3$)$ from H-1' to C-2 $\left(\delta_{\mathrm{C}} 162.0\right)$ and $\mathrm{C}-3^{\prime}\left(\delta_{\mathrm{C}} 18.6\right)$, from $\mathrm{H}-2^{\prime}$ to $\mathrm{C}-2$ and $\mathrm{C}-3^{\prime}$, as well as from $\mathrm{H}-3$ to $\mathrm{C}-1^{\prime}\left(\delta_{\mathrm{C}} 124.8\right)$ proved that a propylene fragment was located at $\mathrm{C}-2$ in compound 3 . In addition, the large coupling constant $(J=15.6)$ between $\mathrm{H}-\mathrm{1}^{\prime}$ and $\mathrm{H}-2^{\prime}$ deduced the E-configuration of $\Delta^{1^{\prime}}$ double bond. Hence, compound 3 was identified and named clapone.

Table 2. ${ }^{1} \mathrm{H}$ and ${ }^{13} \mathrm{C}$ NMR Data for compound 3 in $\mathrm{CH}_{3} \mathrm{OD}$ (500 and $125 \mathrm{MHz}, \delta$ in ppm).

\begin{tabular}{ccc}
\hline \multirow{2}{*}{ Position } & \multicolumn{2}{c}{3} \\
\cline { 2 - 3 } & $\delta_{\mathrm{C}}$, Type & $\delta_{\mathrm{H},}$ Mult. $(\boldsymbol{J}$ in Hz) \\
\hline 1 & - & - \\
2 & $162.0, \mathrm{C}$ & - \\
3 & $109.9, \mathrm{CH}$ & $6.01, \mathrm{~s}$ \\
4 & $182.3, \mathrm{C}$ & - \\
$4 \mathrm{a}$ & $115.8, \mathrm{C}$ & - \\
5 & $143.6, \mathrm{C}$ & - \\
6 & $118.3, \mathrm{CH}$ & $6.64, \mathrm{dd},(2.2,0.8)$ \\
7 & $164.0, \mathrm{C}$ & - \\
8 & $101.8, \mathrm{CH}$ & $6.70, \mathrm{~d},(2.2)$ \\
$8 \mathrm{a}$ & $161.0, \mathrm{C}$ & - \\
$1^{\prime}$ & $124.8, \mathrm{CH}$ & $6.26, \mathrm{ddd}$, \\
& & $(15.6,3.4,1.7)$ \\
$2^{\prime}$ & $137.3, \mathrm{CH}$ & $6.86, \mathrm{ddd}$, \\
$3^{\prime}$ & $18.6, \mathrm{CH}_{3}$ & $(15.6,13.7,6.9)$ \\
$5-\mathrm{CH}_{3}$ & $23.1, \mathrm{CH} \mathrm{CH}_{3}$ & $2.73, \mathrm{~s}, 1.7)$ \\
\hline
\end{tabular}

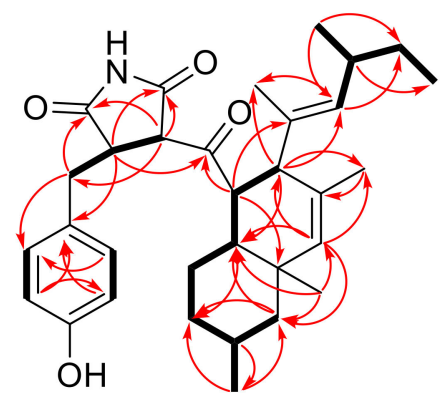

2

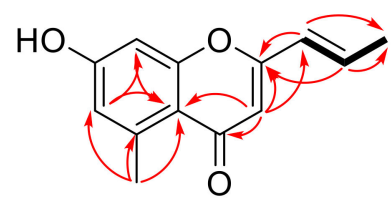

3

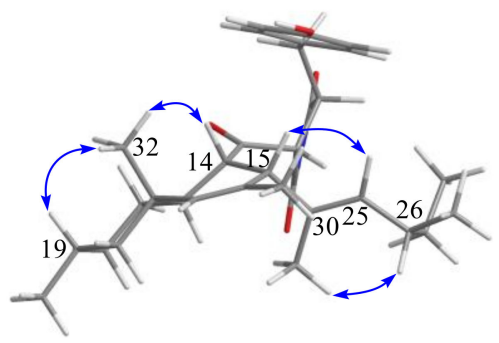

2

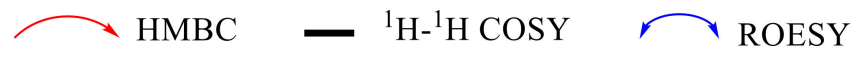

Figure 3. The key 2D NMR correlations for compounds 2 and 3.

\subsection{The Bioactivities of Compounds 1-5 from Cladosporium sp. HNWSW-1}

Compounds 1-5 were tested for their cytotoxicity against Hela, BEL-7042, K562 and SGC-7901 cell lines (Table 3). Compound 2 showed cytotoxicity against the BEL-7042, K562 and SGC-7901 cell lines with $\mathrm{IC}_{50}$ values of $29.4 \pm 0.35 \mu \mathrm{M}, 25.6 \pm 0.47 \mu \mathrm{M}$ and $41.7 \pm 0.71 \mu \mathrm{M}$, respectively. Compound 4 exhibited cytotoxicity against Hela and BEL-7042 cell lines with $\mathrm{IC}_{50}$ values of $14.9 \pm 0.21 \mu \mathrm{M}$ and $26.7 \pm 1.1 \mu \mathrm{M}$, respectively. In addition, all of the compounds were tested for their inhibitory activity against $\alpha$-glycosidase (Table 3). Only compounds $\mathbf{4}$ and $\mathbf{5}$ displayed the inhibitory activity against $\alpha$-glycosidase, with $\mathrm{IC}_{50}$ values of $78.2 \pm 2.1 \mu \mathrm{M}$ and $49.3 \pm 10.6 \mu \mathrm{M}$, respectively. 
Table 3. Cytotoxic and $\alpha$-glycosidase inhibitory activities of $\mathbf{1}-\mathbf{5}$.

\begin{tabular}{cccccc}
\hline \multirow{2}{*}{ Compounds } & \multicolumn{5}{c}{ IC50 $(\boldsymbol{\mu M})$} \\
\cline { 2 - 6 } & Hela & BEL-7042 & K562 & SGC-7901 & $\alpha$-Glycosidase \\
\hline 1 & $>50$ & $>50$ & $>50$ & $>50$ & $>500$ \\
2 & $>50$ & $29.4 \pm 0.35$ & $25.6 \pm 0.47$ & $41.7 \pm 0.71$ & $>500$ \\
3 & $>50$ & $>50$ & $>50$ & $>50$ & $>500$ \\
4 & $14.9 \pm 0.21$ & $26.7 \pm 1.1$ & $>50$ & $>50$ & $78.2 \pm 2.1$ \\
5 & $>50$ & $>50$ & $>50$ & $>50$ & $49.3 \pm 10.6$ \\
Adriamycin & $11.5 \pm 0.18$ & $11.9 \pm 0.37$ & $14.2 \pm 0.66$ & $6.66 \pm 0.2$ & ND $^{\mathrm{a}}$ \\
Acarbose & $\mathrm{ND}^{\mathrm{a}}$ & $\mathrm{ND}^{\mathrm{a}}$ & $\mathrm{ND}^{\mathrm{a}}$ & ND $^{\mathrm{a}}$ & $275.7 \pm 2.7$ \\
\hline
\end{tabular}

${ }^{\text {a }}$ Not detected; Values are expressed as mean \pm standard deviation (SD); $n=3$.

\section{Materials and Methods}

\subsection{General Experimental Procedures}

Silica gel (60-80, 200-300 mesh, Qingdao Marine Chemical Co. Ltd., Qingdao, China), ODS gel (20-45 $\mu \mathrm{m}$, Fuji Silysia Chemical Co. Ltd., Aichi-ken, Japan,), and Sephadex LH-20 (Merck, Kenilworth, NJ, USA) were used for column chromatography. TLC was conducted on precoated silica gel G plates (Qingdao Marine Chemical Co. Ltd., Qingdao, China), and spots were detected by spraying with $5 \% \mathrm{H}_{2} \mathrm{SO}_{4}$ in EtOH followed by heating. Optical rotations were measured on a Rudolph Autopol III polarimeter (Rudolph Research Analytical, NJ, USA). IR absorptions were obtained on a Nicolet 380 FT-IR instrument (Thermo, Waltham, MA, USA) using KBr pellets. 1D and 2D NMR spectra were recorded on Bruker AV III spectrometer (Bruker, Billerica, MA, USA) $\left({ }^{1} \mathrm{H}\right.$ NMR at $500 \mathrm{MHz}$ and ${ }^{13} \mathrm{C}$ NMR at $125 \mathrm{MHz}$ for $2-5,{ }^{1} \mathrm{H}$ NMR at $600 \mathrm{MHz}$ and ${ }^{13} \mathrm{C}$ NMR at $150 \mathrm{MHz}$ for compound 1) using TMS as the internal standard. HRESIMS spectra were recorded with Agilent 6200/6500 iFunnel Q-TOF. Semipreparative HPLC was carried out using an ODS column (YMC-pack ODS-A, $10 \times 250 \mathrm{~mm}, 5 \mu \mathrm{m}$, $4 \mathrm{~mL} / \mathrm{min}$ ). Chem3D Pro 14.0 was the software used for building these 3D models and the calculation method used for energy minimizations.

\subsection{Fungal Material}

The strain HNWSW-1 of Cladosporium sp. was isolated from the healthy tree root of Ceriops tagal, which was collected in the Dong Zhai Gang Mangrove Reserve in Hainan province in July 2011. A healthy root sample of Ceriops tagal was washed in running tap water to remove adhered epiphytes and soil debris. The root surface was sterilized by sequential immersion in $75 \%(v / v)$ ethanol for $3 \mathrm{~min}$ and $5 \%$ sodium hypochlorite solution for $5 \mathrm{~min}$ after drying under sterile conditions, washing the surface-treated roots three times in sterile distilled water after each sterilization. Next, air-dried sterilized roots were cut into about $0.5 \mathrm{~cm} \times 0.5 \mathrm{~cm}$ cubes, deposited on a Potato Dextrose Agar (PDA) (200 g potato, 20 g glucose, $20 \mathrm{~g}$ agar per liter of seawater collected in Haikou Bay, China) plate containing chloramphenicol $(100 \mu \mathrm{g} / \mathrm{mL})$ as a bacterial inhibitor. A reference culture is maintained in our laboratory at $-80{ }^{\circ} \mathrm{C}$. Working stocks were prepared on PDA slants stored at $4{ }^{\circ} \mathrm{C}$.

The fungus was identified based on the DNA sequences (GenBank access No. MH 535968, the the $18 \mathrm{~S}$ rRNA gene sequences data in Supplementary Materials) of 18Sr DNA genes. The mycelium was ground to a fine powder in liquid $\mathrm{N}_{2}$, then genomic DNA was extracted, and the 18S rDNA region was amplified by PCR using primers NS1 (5'-GTAG TCATATGCTTGTCTC-3') and NS6 (5'-GCATCACAGACCTGTTATTGCCT C-3'). PCR products were sequenced (Applied Biosystems 3730 XL Genetic Analyzer, Applied Biosystems Inc., Foster City, CA, USA).

\subsection{Fermentation and Extraction}

Cladosporium sp. HNWSW-1 was cultured in PDB (the potato liquid media consisting of $200.0 \mathrm{~g} / \mathrm{L}$ potato, $20.0 \mathrm{~g} / \mathrm{L}$ glucose, and $1000 \mathrm{~mL}$ deionized water) at $28{ }^{\circ} \mathrm{C}$ and $150 \mathrm{rpm}$ for $72 \mathrm{~h}$. Then $5 \mathrm{~mL}$ 
seed broth was transferred aseptically to $1000 \mathrm{ml}$ Erlenmeyer flasks (60 flasks), each containing rice medium ( $80 \mathrm{~g}$ rice and $160 \mathrm{~mL}$ water). The flasks were incubated at room temperature under static conditions for 60 days. The cultures were extracted three times by EtOAc, and the EtOAc solutions were combined and evaporated under reduced pressure to produce a dark brown gum $(7.1 \mathrm{~g})$.

\subsection{Purification and Identification}

The obtained EtOAc crude extract (7.1 g) was fractionated into 12 fractions (Fr.1-Fr.12) on silica gel VLC and eluted with a gradient elution of $\mathrm{CH}_{2} \mathrm{Cl}_{2}$-petroleum ether $(0-100 \%)$ and $\mathrm{MeOH}-\mathrm{CH}_{2} \mathrm{Cl}_{2}$ $(0-100 \%)$. Fr.6 (2.4 g) was fractionated by RP-18 column chromatography with a gradient of water-MeOH to give 25 fractions (Fr.6.1-Fr.6.25). Fr.6.9 (118.2 mg) was purified by a sephadex LH-20 column ( $40 \mathrm{~g}$ ) and eluted with $\mathrm{MeOH}$ and acetone, respectively, then further submitted to HPLC purification on ODS column eluting with $90 \% \mathrm{MeOH}$ to yield compounds $\mathbf{1}(1.0 \mathrm{mg})$ and 2 (2.1 mg). Fr.6.10 $(72.6 \mathrm{mg})$ was separated by a sephadex LH-20 column $(40 \mathrm{~g})$ and eluted with $\mathrm{MeOH}$ to yield $4(2.0 \mathrm{mg})$. Fr.8 (853.1 mg) was submitted to an RP-18 column and eluted with MeOH-Water to give 7 fractions (Fr.8.1-Fr.8.7). Fr.8.2 (25.2 mg) was separated by a sephadex LH-20 column (15 g) and eluted with $\mathrm{MeOH}$ and further submitted to HPLC purification on ODS column eluted with $35 \% \mathrm{MeCN}$ to yield $3(0.6 \mathrm{mg})$ and $\mathbf{5}(2.2 \mathrm{mg})$.

Cladosporitin A (1): Yellow oil; $[\alpha]_{D}^{20}-166.6$ (c $\left.0.01, \mathrm{CHCl}_{3}\right)$; IR (KBr) $v_{\max }$ : 3290, 2926,1711,1515 $\mathrm{cm}^{-1}$; HRESIMS: $\mathrm{m} / z$ $528.3103[\mathrm{M}+\mathrm{Na}]^{+}$(calcd. for $\mathrm{C}_{32} \mathrm{H}_{43} \mathrm{NO}_{4} \mathrm{Na}, 528.3084$ ); ${ }^{1} \mathrm{H}$ and ${ }^{13} \mathrm{C}$ NMR data: See Table 1.

Cladosporitin B (2): Yellow oil; $[\alpha]_{D}^{20}-94.5$ (c 0.11, $\left.\mathrm{CHCl}_{3}\right)$; IR (KBr) $v_{\max }: 3247,2956,1713$, $1515 \mathrm{~cm}^{-1}$; HRESIMS: $\mathrm{m} / z$ 506.3279 $[\mathrm{M}+\mathrm{H}]^{+}$(calcd. for $\left.\mathrm{C}_{32} \mathrm{H}_{44} \mathrm{NO}_{4}, 506.3265\right) ;{ }^{1} \mathrm{H}$ and ${ }^{13} \mathrm{C}$ NMR data: See Table 1.

Clapone (3): Yellow oil; IR (KBr) $v_{\max }$ : 3435, 2978, 1673, $1400 \mathrm{~cm}^{-1}$; HRESIMS: $m / z 239.0676$ [M + $\mathrm{Na}]^{+}$(calcd. for $\left.\mathrm{C}_{13} \mathrm{H}_{12} \mathrm{O}_{3} \mathrm{Na}, 239.0679\right) ;{ }^{1} \mathrm{H}$ and ${ }^{13} \mathrm{C}$ NMR data: See Table 2.

\subsection{Bioassays for Cytotoxic Activity}

The MTT method optimized by Mosmann et al. [26] was performed in vitro to test the cytotoxic activity of compounds 1-6. Adriamycin was used as a positive control and the medium without the test compound was used as a negative control in the bioassay.

\subsection{Bioassays for $\alpha$-Glycosidase Inhibitory Activity}

The method optimized by Jong et al. [27] was performed in vitro to test the $\alpha$-glucosidase inhibitory activity of compounds 1-5. Acarbose was used as positive control.

\section{Conclusions}

Three new compounds (1-3) along with the previously reported talaroconvolutin A (4) and anthraquinone (5) were isolated from the rice medium culture of mangrove-derived fungus Cladosporium sp. HNWSW-1, isolated from the healthy root of Ceriops tagal collected in the Dong Zhai Gang Mangrove Reserve in Hainan. Their structures were determined by spectroscopic methods. Compound 2 showed cytotoxicity against BEL-7042, K562 and SGC-7901 cell lines with IC 50 values of $29.4 \pm 0.35 \mu \mathrm{M}, 25.6 \pm 0.47 \mu \mathrm{M}$, and $41.7 \pm 0.71 \mu \mathrm{M}$, respectively, while compound 4 exhibited cytotoxicity against the Hela and BEL-7042 cell lines with $\mathrm{IC}_{50}$ values of $14.9 \pm 0.21 \mu \mathrm{M}$ and $26.7 \pm 1.1$ $\mu \mathrm{M}$, respectively. Moreover, compounds 4 and 5 displayed inhibitory activity against $\alpha$-glycosidase with $\mathrm{IC}_{50}$ values of $78.2 \pm 2.1 \mu \mathrm{M}$ and $49.3 \pm 10.6 \mu \mathrm{M}$, respectively. The results suggested that the mangrove-derived fungi are an important source of new bioactive substances. 
Supplementary Materials: The NMR and HRESIMS spectra for 1-3 are available online at http:/ / www.mdpi. com/1660-3397/17/1/4/s1.

Author Contributions: W.M., H.D., and P.W. conceived and designed the experiments; Y.C. performed the isolation of the fungus and the compounds; Y.D. performed the fermentation of the fungus; X.S. collected the root sample of Ceriops tagal; C.C. performed the biological tests; J.Y. and P.C. contributed to the acquirement of the NMR data and IR, respectively; P.W., W.M., H.D., H.C., F.K., and P.C. analyzed the data; P.W., W.M. and H.D. wrote the paper. H.C., F.K. and W.M. reviewed the paper.

Funding: This work was financially supported by Natural Science Foundation of Hainan (No. 217254), National Natural Science Foundation of China (No. 41506096 and 41776093), Financial Fund of the Ministry of Agriculture and Rural Affairs, P. R of China (NFZX2018). Key Laboratory of Tropical Medicinal Plant Chemistry of Ministry of Education, Natural Science Foundation of Hainan Province, and Hainan Normal University (No. 201601).

Conflicts of Interest: The authors declare no conflict of interest.

\section{References}

1. Blunt, J.W.; Copp, B.R.; Keyzers, R.A.; Munro, M.H.G.; Prinsep, M.R. Marine natural products. Nat. Prod. Rep. 2015, 32, 116-211. [CrossRef] [PubMed]

2. Blunt, J.W.; Copp, B.R.; Keyzers, R.A.; Munro, M.H.G.; Prinsep, M.R. Marine natural products. Nat. Prod. Rep. 2016, 33, 382-431. [CrossRef] [PubMed]

3. Blunt, J.W.; Copp, B.R.; Keyzers, R.A.; Munro, M.H.G.; Prinsep, M.R. Marine natural products. Nat. Prod. Rep. 2017, 34, 235-294. [CrossRef] [PubMed]

4. Zhu, H.C.; Chen, C.M.; Tong, Q.Y.; Yang, J.; Wei, G.Z.; Xue, Y.B.; Wang, J.P.; Luo, Z.W.; Zhang, Y.H. Asperflavipine A: A cytochalasan heterotetramer uniquely defined by a highly complex tetradecacyclic ting dystem from Aspergillus flavipes QCS12. Angew. Chem. Int. Ed. 2017, 56, 5242-5246. [CrossRef] [PubMed]

5. Wang, T.T.; Wei, Y.J.; Ge, H.M.; Jiao, R.H.; Tan, R.X. Acaulide, an osteogenic macrodiolide from Acaulium sp. H-JQSF, an isopod-associated Fungus. Org. Lett. 2018, 20, 1007-1010. [CrossRef] [PubMed]

6. Li, H.L.; Xu, R.; Li, X.M.; Yang, S.Q.; Meng, L.H.; Wang, B.G. Simpterpenoid A, a meroterpenoid with a highly functionalized cyclohexadiene moiety featuring gem-propane-1,2-dione and methylformate groups, from the mangrove-derived Penicillium simplicissimum MA-332. Org. Lett. 2018, 20, 1465-1468. [CrossRef] [PubMed]

7. Kong, F.D.; Ma, Q.Y.; Huang, S.Z.; Wang, P.; Wang, J.F.; Zhou, L.M.; Yuan, J.Z.; Dai, H.F.; Zhao, Y.X. Chrodrimanins K-N and related meroterpenoids from the fungus Penicillium sp. SCS-KFD09 isolated from a marine worm, Sipunculus nudus. J. Nat. Prod. 2017, 80, 1039-1047. [CrossRef]

8. Suzuki, S.; Hosoe, T.; Nozawa, K.; Kawai, K.I.; Yaguchi, T.; Udagawa, S.I. Antifungal substances against pathogenic fungi, talaroconvolutins, from Talaromyces convolutes. J. Nat. Prod. 2000, 63, 768-772. [CrossRef]

9. West, P.R.; van Ness, J.; Varming, A.-M.; Rassing, B.; Biggs, S.; Gasper, S.; McKernan, P.A.; Piggott, J. ZG- $1494 \alpha$, a novel platelet-activating factor acetyltransferase inhibitor from Penicilium rubrum, isolation, structure elucidation and biological activity. J. Antibiot. 1996, 49, 967-973. [CrossRef]

10. Sing, S.B.; Goetz, M.A.; Jones, T.; Bill, G.F.; Giacobbe, R.A.; Herram, L.; Mile, S.S.; Williams, D.L. Oteromycin: A novel antagonist of endothelin receptor. J.Org. Chem. 1995, 60, 7040-7042. [CrossRef]

11. Kontik, R.; Clardy, J. Codinaeopsin, an antimalarial fungal polyketide. Org. Lett. 2008, 10, 4149-4151. [CrossRef] [PubMed]

12. Peng, X.P.; Wang, Y.; Zhu, G.L.; Zhu, W.M. Fatty acid derivatives from the halotolerant fungus Cladosporium cladosporioides. Magn. Reson. Chem. 2018, 56, 18-24. [CrossRef] [PubMed]

13. Jadulco, R.; Proksch, P.; Wray, V.; Albrecht Berg, S.; Grafe, U. New macrolides and furan carboxylic acid derivative from the sponge-derived fungus Cladosporium herbarum. J. Nat. Prod. 2001, 64, 527-530. [CrossRef] [PubMed]

14. Zhang, H.; Tomoda, H.; Tabata, N.; Miura, H.; Namikoshi, M.; Yamaguchi, Y.; Masuma, R.; Omura, S. Cladospolide D, a new 12-membered macrolide antibiotic produced by Cladosporium sp. FT-0012. J. Antibiot. 2001, 54, 635-641. [CrossRef] [PubMed]

15. Shigemori, H.; Kasai, Y.; Komatsu, K.; Tsuda, M.; Mikami, Y.; Kobayashi, J.I. Sporiolides A and B, new cytotoxic twelve-membered macrolides from a marine-derived fungus Cladosporium species. Mar. Drugs 2004, 2, 164-169. [CrossRef] 
16. Jadulco, R.; Brauers, G.; Edrada, R.A.; Ebel, R.; Wray, V.; Sudarsono, S.; Proksch, P. New metabolites from sponge-derived fungi Curvularia lunata and Cladosporium herbarum. J. Nat. Prod. 2002, 65, 730-733. [CrossRef] [PubMed]

17. Rotinsulu, H.; Yamazaki, H.; Sugai, S.; Iwakura, N.; Wewengkang, D.S.; Sumilat, D.A.; Namikoshi, M. Cladosporamide A, a new protein tyrosine phosphatase 1B inhibitor, produced by an Indonesian marine sponge-derived Cladosporium sp. J. Nat. Med. 2018. [CrossRef]

18. Wang, L.P.; Han, X.L.; Zhu, G.L.; Wang, Y.; Chairoungdua, A.; Piyachaturawat, P.; Zhu, W.M. Polyketides from the endophytic fungus Cladosporium sp. isolated from the mangrove plant Excoecaria agallocha. Front. Chem. 2018, 6, 344-353. [CrossRef] [PubMed]

19. Sakagami, Y.; Sano, A.; Hara, O.; Mikawa, T.; Marumo, S. Cladosporol, $\beta$-1, 3-glucan biosynthesis inhibitor, isolated from fungus, Cladosporium cladosporioides. Tetrahedron Lett. 1995, 36, 1469-1472. [CrossRef]

20. Yamazaki, H.; Yagi, A.; Akaishi, M.; Kirikoshi, R.; Takahashi, O.; Abe, T.; Chiba, S.; Takahashi, K.; Iwakura, N.; Namikoshi, M.; et al. Halogenated cladosporols produced by the sodium halide-supplemented fermentation of the plant-associated fungus Cladosporium sp. TMPU1621. Tetrahedron Lett. 2018, 59, 59,1913-1915. [CrossRef]

21. Ye, Y.H.; Zhu, H.L.; Song, Y.C.; Liu, J.Y.; Tan, R.X. Structural revision of aspernigrin A, reisolated from Cladosporium herbarum IFB-E002. J. Nat. Prod. 2005, 68, 1106-1108. [CrossRef] [PubMed]

22. Liang, X.; Huang, Z.H.; Ma, X.; Qi, S.H. Unstable tetramic acid derivatives from the deep sea-derived fungus Cladosporium sphaerospermum EIODSF 008. Mar. Drugs 2018, 16, 448. [CrossRef] [PubMed]

23. Zhu, G.L.; Kong, F.D.; Wang, Y.; Fu, P.; Zhu, W.M. Cladodionen, a cytotoxic hybrid polyketide from the marine-derived Cladosporium sp. OUCMDZ-1635. Mar. Drugs 2018, 16, 71. [CrossRef]

24. Zhao, D.L.; Wang, D.; Tian, X.Y.; Cao, F.; Li, Y.Q.; Zhang, C.S. Anti-phytopathogenic and cytotoxic activities of crude extracts and secondary metabolites of marine-derived fungi. Mar. Drugs 2018, 16, 36. [CrossRef] [PubMed]

25. Matsunaga, H.; Kamisuki, S.; Kaneko, M.; Yamaguguchi, Y.; Takeuchi, T.; Watashi, K.; Sugawara, F. Isolation and structure of vanitaracin A, a novel anti-hepatitis B virus compound from Talaromyces sp. Bioorg. Med. Chem. Lett. 2015, 25, 4325-4328. [CrossRef] [PubMed]

26. Mosmann, T. Rapid colorimetric assay for cellular growth and survival: Application to proliferation and cytotoxicity assays. J. Immunol. Methods 1983, 65, 55-63. [CrossRef]

27. Jong, A.N.; Bhandari, M.R.; Kawabata, J. $\alpha$-Glucosidase inhibitors from Devil tree. Food Chem. 2007, 103, 1319-1323. [CrossRef] 